\title{
The potential of using script theory in consumer behaviour research
}

\author{
Alet C Erasmus, Elizabeth Boshoff and GG Rousseau
}

\begin{abstract}
OPSOMMING
Die schema-konsep is in 1932 deur Bartlett, 'n sielkundige, bekendgestel as 'n denkbeeldige voorstelling van ' $n$ bepaalde ondervinding. Hy het beweer dat ' $n$ individu se ondervindinge in die geheue gerasionaliseer, aangepas en verdraai word binne die raamwerk van bestaande schemata (Shute, 1996:410). Ongelukkig is daar eers twee dekades later aan sy werk aandag gegee en toe weer in die 1970 's in die kognitiewe sielkunde. Schank en Abelson (1977 in Eysenck, 1994:316 ) het die idee van schemata uitgebrei om te verduidelik hoe kennis van meer komplekse gebeure in ' $n$ bepaalde orde in die geheue vasgelê word. Daar is na hierdie kennisstrukture as "geskrifte" verwys.
\end{abstract}

Geskrifte word op verskeie maniere gedefinieer: Puto (1985:404) definieer ' $n$ geskrif as ' $n$ aantal verbandhoudende gebeure wat deur ' $n$ individu - as deelnemer of waarnemer - in 'n bepaalde konteks verwag word. 'n Geskrif word ook beskryf as 'n denkbeeld met byskrifte wat die volgorde van aksies, deelnemers en fisiese objekte wat in die situasie teenwoordig is insluit (Abelson, 1981 in Schurr, 1986:498).

Geskrifte as ' $n$ vorm van verklarende kennis verwys na die strukturele aard daarvan en ook die wyse waarop geskrifte in die geheue georganiseer is (Matlin, 1998:231, 232). Geskrifte het bepaalde eienskappe (Bower et al, 1979 in Bozinoff \& Roth 1983:656) en verskeie strukturele kenmerke wat hulle van ander denkraamwerke onderskei (Thorndyke \& Yekovich in Smith \& Houston, 1986:504) en hulle besonder bruikbaar maak vir die bestudering van verbruikersgedrag.

Die feit dat geskrifte generiese inligting bevat wat in terme van die volgorde van aktiwiteite/aksies saamgestel is, bied die moontlikheid om geskrifte te ondersoek om spesifieke gebeure - selfs aankoopgebeurtenisse - voor te stel. Een van die voordele van 'n geskrif is juis dat dit op die perspektief van die verbruiker gebaseer is. Per definisie spesifiseer geskrifte al die deelnemers en rolspelers sodat ' $n$ meer realistiese scenario van die gebeurtenis gestel kan word. In hierdie literatuuroorsig word die teorie van geskrifte bespreek en voorgestel as 'n moontlikheid om verbruikersbesluitnemingsgedrag bloot te lê in plaas daarvan om tradisionele verbruikersbesluitnemingsmodelle te gebruik waaraan navorsers en akademici al so gewoond geraak het.

\section{- Mrs AC Erasmus \\ - Prof E Boshoff}

Department of Consumer Science

University of Pretoria

- Prof Gg Rousseau

Department of Industrial Psychology

University of Port Elizabeth

\section{INTRODUCTION}

The purchasing of household appliances (durables) is typically categorized as a complex, high-risk consumer decision. Because of the fact that there are very few decision-making models that reflect specific purchasing events such as the acquisition of household appliances, traditional consumer decision-making models are generally used to structure and interpret consumer behaviour research - even for product specific research. These models provide broad, organized structures that reflect consumer decision-making from different viewpoints and within different contexts but inevitably mean that the research approach has to coincide with the assumptions of the original authors. Generalizing consumer decision-making to such an extent for any consumer product unfortunately implies a biased approach to consumer decision-making from the start (Burns \& Gentry, 1990: 522).

Researchers have become increasingly critical in recent times objecting to the use of traditional consumer decision-making models without careful premeditation of the context and purpose within which it is used. Since 1978 several arguments against the general use of traditional consumer decision-making models have been raised. Schurr (1986: 498), in reaction to such objections, for example postulated that purchasing scripts could result in accurate predictions of buyer attitudes and judgment.

Scripts, also known as event schemata, are memory structures that are well-known in the field of cognitive psychology. By definition scripts - if elicited and generated for specific events - could also be of value in the field of consumer science because of a script's potential to be used to describe and even predict consumer behaviour in specific circumstances. The potential of scripts to provide behavioral guidance (Searleman \& Herrmann, 1994:126; Stoltman, Tapp \& Lapidus, 1989:385; Weisberg, 1980:56) and to reflect on the interaction of individuals and information in decision-making (Taylor, Cronin \& Hansen, 1991:17) has been raised before. Various researchers in the field of consumer behaviour have found memory schemata to be important in the structure of consumer knowledge (Leigh \& Rethans, 1983:668; Whitney \& John, 1983:661-663; John \& Whitney, 1982:75). From these reports it seems that scripts could be used to reflect specific types of consumer/buyer behaviour. There is substantial evidence that people form and use scripts from a very early age (Searleman \& Herrmann, 1994:126; Hoy, 1991:387). These scripts are stored in long-term memory and are activated and used automatically to guide behaviour in specific circumstances (Bozinoff, 1982:481). 
A study of consumer decision-making for major household appliances, and more specifically an attempt to elicit and organize a specific script to be used as an alternative to traditional consumer decisionmaking models, therefore seems to coincide with recommendations for future research in the field of consumer behaviour. The script concept is generally accepted to be a valid construct with wide application (Taylor et al, 1991:17) and has been applied in areas such as cognitive, social, developmental and clinical psychology as well as cognitive anthropology as noted by Rummelhart (1980) and Abelson (1976) in Leigh \& Rethans (1983:667) as well as Barlett (1932), Bransford and Franks (1971), Minsky (1975), Rumelhart and Ortony (1977), Schank and Abelson (1977) and Mandler (1979) as cited by John and Whitney (1982:75). Despite the popularity of the script concept in psychology, no empirical use of scripts in the study of consumer decision-making has been reported until the early 1980's (Leigh \& Rethans, 1983: 667; Whitney \& John, 1983: 661). Since the introduction of scripts within the domain of consumer behaviour and since the first script elicitation studies by Whitney and John in 1983 (shopping script) and Stoltman et al in 1989 (examination of shopping scripts), little has been done to extend and implement the concept in practice (Stoltman et al, 1989:384).

Script theory's potential application in consumer behaviour research lies in the possibility that scripts (per definition) could shed light on consumers' expectations, pro-active planning as well as situational decision making processes and behaviour. The purpose of this literature review is to give an overview of basic script theory and consequently to explain the potential of scripts to serve as a representation of specific purchasing events. Scripts must however at this point be differentiated from frames: according to Collins, Gathercole, Conway and Morris (1993:41-43) both represent the structural properties of human knowledge in memory, although frames specifically refer to the recursive decomposition of specific components (concepts) in a memory structure (for example STORE VISIT can be divided into COLLECTING PRODUCT INFORMATION and COMPARING PRODUCT ALTERNATIVES while both can be further decomposed into separate frames, for example LISTING PRICE DIFFERENCES; STUDYING DIFFERENT BRAND NAMES).

The purpose of this overview is to discuss the possible existence of a script for a specific purchasing event in memory and to deliberate the structure and content of such a script rather than to focus on a detailed breakdown of each of the elements of the script into specific frames. This could, however, become the focus of a follow-up study.

\footnotetext{
${ }^{1}$ Rousseau developed a model of adult purchase decision-making process for furniture (Du Plessis \& Rousseau, 1999:91).
}

\section{BACKGROUND OF THE SCRIPT THEORY}

The term schema as used in psychology, originated through work of Piaget (1926) and Bartlett (1932). It was Bartlett who described schemata as hypothetical mental constructs (abstract knowledge structures) that control attention and the reconstruction of memory and enables one to recognize and recall things that you have been exposed to before (Abelson, 1981:715). The formation of schemata is for example described as an early memory occurrence that provides a young child with a basic representational system to cope in real life situations (Hoy, 1991:387). Bartlett further postulated that an individual's original experience of an event undergoes processes of rationalization, elaboration and alteration within preexisting schemata in memory over time within the limitations of one's cognitive development (Shute, 1996:410). He thus proposed memory to be a reconstructive process that involves interpretation of stimuli, and more importantly, the continual transformation of the original schemata (Matlin, 1998:6). Unfortunately an overriding dedication to the use of experimental methods of behaviourism in research during that time caused Bartlett's work to be ignored until American cognitive psychologists regained interest in the schema theory almost two decades later.

Contemporary cognitive psychology that includes themes such as attention, memory, concept formation and problem solving dates back to 1956. Cognitive psychology is part of a broader field, namely Cognitive Science that has particular interest in the human mind (Matlin, 1998:10). When the schema concept once again attracted interest in the cognitive psychology in the 1970's, Schank and Abelson (1977) as reported by Eysenck (1994:316) extended the idea of schemata to explain how knowledge of more complex event sequences is represented in memory. Such knowledge structures were referred to as scripts and represent elements indicative of repeated experiences of events. According to script theory - that is a specific elaboration of Minsky's frame theory (Bower, Black \& Turner, 1979:178) - a script consists of a sequence of goal directed actions that are causally and temporally ordered and includes the relevant people, objects and locations (Sutherland, 1995:413; Bower et al, 1979:178).

Experimental evidence of the psychological reality of schemata and scripts has accumulated since (Vosniadou, 1996:403; Eysenck, 1994:316, 317; Searleman \& Herrmann, 1994:125). Modern versions of the schema theory play a prominent role in current theories of memory (Eysenck, 1994:316). Of specific importance for this article, is that theorists within the broad field of cognitive science propose that thinking involves the manipulation of internal representations (mental models) of the external world (Matlin, 1998:10). The schema concept, as developed by Bartlett in 1932, still forms an integral part of the paradigm of cognitive psychology. 


\section{SCRIPTS AS A SPECIFIC FORM OF SOCIAL SCHEMATA}

\section{Categories of schemata}

Social schemata are cognitive structures that are categorized into four groups (Taylor et al, 1991:15), namely self schemata (that contain information about one's own personality, appearance, behaviour); person schemata (that focus on traits and behaviours common to types of people); role schemata/ person in- situation schemata (that include information about people and their typical behaviour in specific social situations) and event schemata/ scripts (that include knowledge about the expected sequence of events in a given situation). A script therefore is a social schema with specific characteristics. To fully understand scripts, the relevant concepts are defined and discussed first.

\section{Definition and discussion of relevant and related concepts}

Schema/ta According to the standard theory in cognitive psychology, schemata are stored frameworks (cognitive structures) of knowledge about specific objects or topics and are represented by nodes in semantic memory ${ }^{2}$ (Brown, 1992:787). Schemata thus contain units of information that are interconnected to form an integrated whole (Alba \& Hasher, 1983; Bartlett 1932; Fiske \& Dyer, 1985 in Taylor et al, 1991:15) and can be described as abridged, generalized, corrigible organizations of experience that serve as initial frames of reference for action and perception of similar experiences (Weick in Schurr, 1986:498). A schema in part consists of a defined stimulus domain, is linked to a specific experience and contains general/generic knowledge about that domain including the relationships among its attributes and examples of instances of the stimulus domain. When one is exposed to any object or situation, a schema is retrieved from long-term memory into working memory to serve as a frame of reference so that one is able to interpret, accept and understand the object/situation (Brown, 1992:787; Hoy, 1991:387).

A schema assumes the operation of four mental processes: the selection of incoming stimuli for mindful presentation and interpretation using prior knowledge to support the comprehension and integration for storage in the memory (Schurr, 1986:498). Individuals eventually rely upon stored, generic concepts/events in a schema to solve problems, to set goals, select behaviour or to provide direction for further information search (Leigh \& Rethans, 1983:667; Whitney \& John, 1983:661). According to the schema theory, we summarize the regularities in our lives and after a while, any single event can no longer be distinguished from other similar events. We in fact reconstruct generic representations of similar events (Matlin, 1998:158). Schema theory thus refers to the interpre-

\footnotetext{
2 Semantic memory refers to so-called general knowledge.
}

tation of experience rather than the exact representation of experiences (Thagard, 1998:60; Shute, 1996:410).

Schema theories have been proposed as a means whereby individuals deal with the overwhelming amount of information in the environment: a schema enables selective perception in every day living by controlling information selection and focusing attention on a limited portion of stored knowledge (Schurr, 1986:498).

Schemata in terms of knowledge and cognitive structures A cognitive process refers to the way in which consumers (human beings) process information (Schurr, 1986: 498; White, Curbow, Constanzo \& Pettigrew, 1983:636). According to the standard theory of cognitive structure, knowledge is stored in long-term memory as schemata (see Figure 1). Schemata refer to large sets of well-structured cognitions that have been learned over time with experience (Lindsay \& Norman, 1975, Norman \& Bobrow, 1975 in Bozinoff \& Roth, 1983:655: Abelson, 1981:715) and consist of frameworks for organizing information about a concept into a meaningful structure (Ashcraftt, in Brown, 1992:787; Bozinoff \& Roth, 1983:655; Bozinoff, 1982:481). One would therefore not be able to recognize an object such as a washing machine unless one has a conception or schema of what a washing machine is (Taylor \& Crocker, 1981 in Whitney \& John, 1983:662). Schemata are regarded as the building blocks for cognition (Leigh \& Rethans, 1983:667) but they are not static: they are the result of a continuous cognitive process and change with experience (Whitney \& John, 1983:661).

Any information that an individual is exposed to is organized in memory through schemata, to give meaning to stimuli and to enable interpretation and comprehension of any situation as new, familiar or unique. According to Lord and Foti (1986, in Taylor et al, 1991:15) people depend on such highly structured knowledge systems to conclude appropriate subsequent behaviours. Schemata in essence provide a knowledge base that serves as a control mechanism to facilitate (or limit) one's understanding of the world and events and to assist individuals to effectively deal with complex tasks (Fayol \& Monteil, 1988, Lord \& Foti, 1986 in Taylor et al, 1991:16).

According to Fayol and Monteil (1988, in Taylor et al, 1991:16) schemata can be executed automatically when needed while Langer, Blanck and Chanowitz (1978, in Taylor et al, 1991:16) concluded that individuals unconsciously categorize facts they are confronted with and then act upon them automatically. However, when an individual is exposed to an unfamiliar situation where stimuli do not correspond with his expectations of the situation, mental thought becomes conscious and the semantic content (general knowledge) will dominate (Leyens, 1983 in Taylor et al, 1991:16).

Scripts Scripts are a specific form of schemata, namely event schemata and can be described as tem- 
porally and sequentially ordered schemata (hypothetical knowledge structures) in long-term memory that contain series of actions which are arranged in the hierarchical or causal ordering of their elements (Whitney \& John, 1983:662). A number of more detailed definitions for scripts exist, all referring to the same phenomenon but emphasizing different dimensions. Puto $(1985: 404)$ for example defines a script as a coherent sequence of events expected by an individual in a particular context, involving him either as participant or as an observer. A restaurant script, for example, may therefore contain scenes/ elements such as entering, being seated and ordering and certain schemata, such as the waiter may represent certain significant components of that script. Abelson (1981:718) describes scripts as rich packages of information and preferred a more visual definition: he regarded a script as a mental picture plus caption - representing the action sequences, participants, and physical objects found in a situation.

Because a script is a structure that consists of interconnected elements, the actions in one slot affect the contents of the other (Schank \& Abelson, 1977 in Whitney \& John, 1983:662; Den Uyl \& Van Oostendorp, 1980:278). Scripts that have been stored in an individual's memory include routine, well-practiced event sequences and over time. Through continuous learning, the application of scripts in real life situations becomes automatic (Speck, Schumann \& Thompson, 1988:70; Bozinoff \& Roth, 1983: 655,656; Whitney \& John, 1983: 661). In practical terms it means that scripts are used in situational context to direct behaviour when activated (Sutherland, 1995:413; Stratton \& Hayes, 1993:173; Whitney \& John, 1983:662; Bozinoff, 1982:481). Scripts are particularly valuable because they conserve effort. A script for example enables someone to act instead of relearning the steps of appropriate buying behaviour with every subsequent purchase (Martin, 1991:225). Individuals can consciously extract from their scripts when asked to describe familiar activities. The result is an automatic process although the initial development of scripts is conscious. A situation therefore triggers the appropriate script or part of a script (subscript) and guides behaviour (Stoltman et al, 1989:384) as it specifies the events that can normally be expected to occur (Taylor et al, 1991:18; Puto, 1985:404).

In psychology, attempts have been made to broaden and define script content by identifying the common and unique properties of scripts (Stoltman et al, 1989:384). Scripts were found to be a function of the context. A generic restaurant script should thus be replaced by a fine dining script or a fast food restaurant script to fully capture the unique characteristics of the different events. Of special interest to the discipline of consumer science, is the premise that the development of a generic script for any specific consumer decision-making situation will provide a basic scenario that could be adapted for similar decisionmaking situations - thus establishing a whole new avenue to explore.
Metascripts In addition to the script concept, socalled metascripts or memory organization packages (MOPs) exist (Abelson, 1981:726). These refer to a family of knowledge structures that are stored as reminders or to facilitate understanding through previous experiences. For any individual, separate experiences (for example buying experiences) may contain sufficient subjective similarity to achieve coherence despite differences in detail (shopping for clothes would include a scene for fitting of clothes while shopping for appliances will not). Ultimately, the presence of salespeople, the display of appliances/ garments will evoke similar cognitive representations and these will form part of a metascript. The metascript concept provides the opportunity to adapt a script to portray other, similar events (Forrest-Presley, MacKinnon \& Waller, 1985:111-115).

Scripts versus frames, habits and stories There is a distinction between scripts, frames, habits and stories in terms of cognitive involvement and detail provided.

- Both scripts and frames can be described as representations of knowledge in memory with multiple levels of hierarchical structure. A script more specifically refers to event schemata that consist of various elements in a specific hierarchical order while any single element of a script (for example STORE VISIT can be interpreted as a frame that can be further divided into COMPARISON OF PRODUCTS which is a frame in itself and DELIBERATION OF ALTERNATIVES which is another frame of knowledge) (Collins et al, 1993:41-43). Frame theory is popularly implemented in artificial intelligence and has potential in production systems while scripts specifically refer to event schemata (Collins et al, 1993:43).

- According to Langer and co-workers (1978, 1979 in Whitney \& John, 1983:662), script processing requires a certain amount of conscious thinking (e. g. where to sit in the restaurant and what to order). It is only when the sequence of actions are disturbed or when the actions differ from what is expected (for example when no menu is provided in the restaurant), that conscious thinking takes over and the consumer calls upon the waiter for assistance so that a meal may be ordered (thus for scripted activities to proceed). Although a script is activated automatically it does not imply mindless behaviour. For scripts, the cognitive aspect that is involved is explicit in the specified event sequences and when one is confronted with variations to constancies and needs to adapt (Abelson, 1981:722). There can for example be different script paths/tracks offering different alternatives to normal procedures: if the menu is on the table, the waiter need not be asked for one (restaurant script); if payment options are displayed obviously in the store, a salesperson need not be asked for such details (buying script).

- Habits, on the other hand, do not provide for such variations and refer to (mindless) response behaviour (for example paying by credit card for the meal every time you go to a restaurant). A script could in 
some instances become a habit, for example when someone always sits in the same corner and always orders the same meal (Whitney \& John, 1983:662).

- In contrast to a script that is generic in nature with no detail included, stories contain more detail relating to specific experiences (Whitney \& John, 1983:662; Abelson, 1981:723).

\section{EMPIRICAL EVIDENCE FOR SCRIPTS}

Since the introduction of scripts, various efforts have been made to find empirical evidence for scripts. Bartlett (1932) found that when subjects were given stories to memorize, they tended to adapt the stories to conform to their own ideas/scripts, in other words to coincide with existing knowledge. Bozinoff and Roth (1983:656) suggest that subjects store experiences in the form of scripts and then draw upon their own scripts to complete stories. Other studies cited by Bozinoff and Roth (1983:656, 657) confirm this: for example Brandsford, Barclay and Franks (1972) found that when questioned, subjects tend to construct semantic descriptions of situations rather than to remember the details of information that were presented to them. Baggett (1975 quoted by Bozinoff \& Roth, 1983:656, 657) also found that during a memory task, subjects filled in missing details based on their own experience to complete a story. This means that scripted information stored in memory, is used to fill in missing information.

Parental descriptions of toddlers' pretended shopping behaviours (Hoy, 1991:387) suggest the emergence of script-related knowledge at a very early age: childdevelopment literature in fact suggest that children at the age of 24 months already possess sufficient cognitive and social skills to acquire rudimentary consumer knowledge. The script framework has also been used to describe children's socialization as consumers (Schank \& Abelson, 1977 in Hoy, 1991:387; Forrest-Presley et al, 1985:45).

The formation of scripts, however, is an individual phenomenon. Scripts for the same event (e.g. the purchasing of a house or major household appliances) will therefore differ from person to person although such scripts will agree on the most significant aspects so that a so-called shared script could be inferred. This is ascribed to the fact that scripts are developed through interaction with the environment (Nottenburg \& Shoben, 1980: 330).

\section{SCRIPTS AS PERFORMANCE STRUCTURES AND IN TERMS OF INFORMATION PROCESSING CA- PACITY}

Scripts are knowledge structures that play a dual role: they can be categorized as scripts in understanding and scripts in behaviour (Abelson, 1981:719; Bower et al, 1979:178). By retaining and then retrieving actions from previous experiences, scripts facilitate the understanding of events/situations and also direct behaviour so that new actions need not be learned for similar situations (Bozinoff \& Roth, 1983:655). According to Taylor et al (1991:16), scripts also contribute to the understanding of the behaviour of others. Scripts consequently guide behaviour as well as the appropriate sequence of actions in a specific context so that the individual does not have to devote full attention to incoming stimuli (Puto, 1985:404; Whitney \& John, 1983:663, 664). Scripts thus contribute to comprehension (Gibbs \& Tenney, 1980:275-284; Nottenberg \& Shoben, 1980:330) by providing a structure of how the world operates from personal or explicit experiences by guiding lower-order information processing (Leigh \& Rethans, 1983:667; Abelson, 1980 \& Martin, 1980 in Whitney \& John 1983:662). Because a script signifies stereotypic conception, it facilitates the ordering of incoming information. Individuals thus use scripts as an aid to plan, handle and understand situations and activities (Bower et al, 1979:178).

Although scripts are initially developed in a conscious learning context, an activated script will probably result in automatic or routine response with little conscious effort required due to the fact that familiar activities, through over learning, eventually become automatic (Speck et al, 1988:70; Bozinoff \& Roth, 1983:655, 656; Whitney \& John, 1983:661). The situation therefore triggers the appropriate script in memory and provides behavioural guidance (Stoltman et al, 1989:384). When an individual has to react to a stimulus that differs from what is preserved in the script in memory, the script will dominate so that the individual will be inclined to act in terms of the script. Of specific interest for the theory of consumer decision-making is the characteristic of a script to conserve a consumer's limited information processing capacity and to reduce cognitive strain due to encoding and retrieval processes from memory. A script facilitates action by minimizing effort and it reduces information overload by stimulating selective attention to information/stimuli (Taylor et al, 1991:16; Leigh \& Rethans, 1983:667; Whitney \& John, 1983:662; Bozinoff, 1982:481).

\section{PROPERTIES AND STRUCTURAL CHARACTERIS- TICS OF SCRIPTS}

Although different scripts exist in memory as a function of contextual cues and also as a result of core and peripheral actions (Stoltman et al, 1989:384), studies have indicated that scripts possess certain properties (Bozinoff \& Roth, 1983:656; Bower et al, 1979:177-179):

- There are script norms: a script for a specific event always contains the same characters (people), props (objects) and actions and is further characterized by a specific order of events, thus a specific bundle of expectations about the event. Script norms are also referred to as sets of $v i$ gnettes (Abelson, 1981:717). (Example of a vignette: The waiter (character) presents (action) the menu (object) to the client (character).

- Within a script, series of action sequences are al- 
ways grouped into segments/scenes/elements in a similar way so that any script contains several elements that represent the characteristic grouping of actions. Each element has a definite main conceptualization or MAINCON (Abelson, 1981:717), in other words one or more central or top-level events that always take place (Den Uyl \& Van Oostendorp, 1980:278) (Examples of MAIN CONS in a restaurant script: Ordering the meal; Paying the bill) (Bozinoff \& Roth, 1983:656).

- Script elements are always organized in a common order. Research has shown that when the series of actions for a specific event are scrambled out of order, subjects tend to use a common order to unscramble and organize them.

- Subjects are not conscious of scripted activities due to the automatic nature of scripts and the fact that scripts are stored in long-term memory, which make it rather difficult to retrieve in an experimental situation. As a result, when confronted, subjects often remember exceptional actions rather than scripted ones (Graesser, Gordon \& Sawyer, 1979 and Graesser, Woll, Kowalski \& Smith, 1980 in Bozinoff \& Roth, 1983:656). Subjects do however have the ability to draw upon scripts to describe familiar activities on condition that they have to be prompted very specifically within a specific context to successfully elicit scripted activities.

Several structural characteristics differentiate scripts from other memory presentations (Thorndyke \& Yekovich in Smith \& Houston, 1986:504):

- Scripts only contain the common (generic) actions for a prototypical event and can be described as a network of generic actions that are combined according to certain rules - almost like a model or framework that needs to be elaborated with detail (Morris, 1987:189; Abelson, 1980 in Bozinoff \& Roth, 1983: 655). Scripts thus contain a specific nature of knowledge (concept abstraction) excluding the details of the event.

- Scripts possess a set quality: when access is gained to any component action (element) of a script, access to the entire group of actions constituting an event is obtained because the various elements are linked and interconnected. An individual will thus automatically respond to the situation taking into account the entire event including the preceding actions (Smith \& Houston, 1986: 505).

- Temporal or causal sequence is typical of a script's organization. Certain actions must therefore precede other actions in time in a particular set to provide the enabling conditions for the latter actions to occur (for example reading the menu before ordering the meal) (Thorndyke \& Yekovich in Smith \& Houston, 1986:504).

- Scripts possess a hierarchical structure that determines the relationships among actions of varying levels and how they interconnect to constitute an event (Smith \& Houston, 1986:504). Abbott and Black (1980, in Smith \& Houston, 1986:504) describe this hierarchy in three levels namely a script header, scene headers and scene actions. A script header represents the macro level of the hierarchy and summarizes the entire event (e.g. dining in a restaurant). The event consists of several scenes, identified by scene headers (e.g. entering the restaurant) that exist at an intermediate level of the hierarchy and contain more detailed information/scene actions. The scene actions are at the lowest level of the hierarchy and include the individual actions relevant to a specific scene (Example: The Ordering scene in the restaurant script may consist of Reading the menu; Discussing the choices; Placing an order) (Smith \& Houston, 1986:504).

- Scripts may also vary in strength: strong scripts are more explicit and contain several scene constraints, in other words many actions that must occur. Weak scripts, on the other hand, are vague and have fewer scene constraints so that some scenes do not have a high probability of occurring (Example: A strong restaurant script (fine dining) will always have a waitress while a weak script (fast foods restaurant) need not) (Bozinoff \& Roth, 1983:655; Abelson, 1981:717).

- Script events may also vary in degree of centrality: more central events are referred to as main conceptualizations around which other aspects of the script are organized. Idiosyncratic differences would be expected for less central events that reflect unique personal experiences (Whitney \& John, 1983:662).

\section{RELEVANT LEARNING THEORY}

In cognitive psychology it is understood that people interpret the world in terms of concepts that are organized into large conceptual structures within memory (Vosniadou, 1996:402; Lai, 1994:491). It is further proposed that people comprehend complex sequences of events in memory structures known as schemata, scripts and frames. Schemata (and scripts) are presumed to be represented in memory in an abstract form (bearing no direct relationship to a given form of perception e.g. visual, auditory, tactile). They are further presumed to be stored as frameworks of knowledge in long-term memory with their defining characteristics contained in a propositional format, organized according to specific rules for use in subsequent acquisition of declarative knowledge (Shute, 1996:416; Vosniadou, 1996:404; Brown, 1992:787; Bozinoff, 1982:481). Scripts as form of declarative knowledge refer to the structural nature of scripts, i.e how scripts are organized in memory (if this happens, then that follows (Matlin, 1998:231, 232).

Declarative knowledge more specifically refers to the organization of propositions, concepts and schemata in the various conceptual structures in memory (Matlin, 1998:230; Shute, 1996:414; Vosniadou, 1996:404). According to Andersen's ACT* (ACT star) theory declarative knowledge refers to knowledge about facts and things. It further proposes that the 
declarative network consists of an interconnected set of propositions. An example would be washing machines sold at specific stores in specific departments. Another example would be visual images in stores, of all the washing machines displayed together or information about the order of events for example deciding what type of washing machine is required before buying (Matlin, 1998:230). Associative processes and inductive reasoning are used to produce declarative knowledge outcomes.

According to the constructive model of memory, schemata facilitate memory abstraction so that one is able to understand and interpret an event even without details about the original event (Matlin, 1998:256). A script is considered to be a prototype of a sequence of events (Matlin, 1998:245) and creates strong expectations about the event that affect and enable the interpretation of information. There is evidence that scripts (stereotypical event schemas) influence the way in which people remember information and make inferences in complex situations (Vosniadou, 1996:403).

The use of scripts to recognize situations, refer to topdown cognitive processing (concept driven processing) that refers to the influence of concepts, expectations and memory to conclude appropriate behaviour (Matlin, 1998:21). These conceptual structures in memory are continuously modified to incorporate experience and this explains why individual scripts for the same event will differ in certain aspects (Matlin, 1998:165; Shute, 1996:416; Vosniadou, 1996:404): enrichment refers to the addition or deletion of concepts in memory; tuning refers to the evolutionary changes in the application of schema to interpret data; accretion refers to gradual accumulation of information, while restructuring refers to the creation of new knowledge structures.

Script theory is based upon the existence of higher order memory structures and involves unique access to entire sets of knowledge in memory. Speck et al (1988:70) refer to Brewer and Namakura (1984) and Alba and Hasher (1983) who explain script theory in terms of selective attention, encoding and retrieval, information processing and then emphasize relational context as the basis of meaning. The implication of the learning theory (more specifically the basic theories of cognition) for schema research, is that experience is an important prerequisite for participation in a script elicitation study to ensure that participants have been exposed to conditions over time that would have allowed for the formation of the desired complex, abstract schemata/scripts in long-term memory.

\section{RATIONALE FOR THE ELICITATION OF SPECIFIC SHOPPING SCRIPTS}

A major advantage of a script is that it contains a sequence of events from the point of view of the consumer (Abelson, 1981:715) and ultimately has the potential to offer valuable insights into consumer be- haviour (Taylor et al, 1991:16). Taylor et al (1991:17) refer to Barsalou and Hutchinson (1986) who investigated the role of schemata in planning and concluded that consumers use the most general aspects of schema knowledge on most occasions while other types of information tend to be more variable and context specific. From this it seems that scripts could provide a mechanism for linking expectations (assumed to be based on scripts) with both proactive planning as well as the situational decision-making process. In contrast to consumer decision-making models, scripts categorically identify principle actions, the people (actors) and the objects involved in a recurring situation/event. Scripts thus have the advantage over consumer decision-making models in the sense that scripts facilitate the study of individuals (consumers and other role players), objects and roles within specific decision-making contexts (Calder \& Schurr, 1981 in Speck et al, 1988:70; Schurr, 1986:498-501). Because scripts reflect consumers' mental representation of an event (i.e. actual behaviour in the minds of consumers) (Bozinoff, 1982:485), scripts could provide valuable guidelines on how to go about changing/adapting consumer behaviour. An understanding of script theory also serve as a reminder that consumers tend to act on what they are familiar and comfortable with and are reluctant to learn/accept new ideas so that they are inclined to revert to scripted activities that are somewhat related to routine response behaviour (Bozinoff \& Roth, 1983:659).

It is suggested that research on scripts and more specifically an effort to successfully elicit and organize scripts for specific consumer decision-making activities, will contribute to expanding theory in consumer/ buyer behaviour. This will be to the benefit of:

- Consumers. Scripts identify the people and objects involved in an event as well as the actions taken. The elicitation of scripts for specific events/ activities will result in an improved understanding of actual buyer behaviour. Consequently consumer assistance could be planned and directed more effectively instead of it being irrelevant, haphazard, confusing and even overwhelming.

- Retail and industry. Scripts can provide an avenue to plan more effective marketing strategies in the sense that a script provides a more realistic reflection of the decision-making process as it is generated from the view of the consumer. The relevant people can be targeted and the type of assistance can be provided, where and when it is needed most.

- Consumer advisors. Because scripts reflect buyer behaviour from the perspective of consumers, it will be possible for consumer advisors employed by suppliers of goods and services to provide assistance where and when required rather than to focus on what is assumed to be important.

- The market-place. Scripts have the potential to shed light on buyer behaviour so that the inputs and contributions of the parties involved in the process can be planned and coordinated to the benefit of all. 
- Consumer education. Scripts provide information (for example on information search and financial decision-making) that may assist or serve as guidelines in consumer-education programmes at school or tertiary institutions.

\section{CONCLUSION}

It must be appreciated that traditional consumer decision-models have, up to now, made an important contribution to concept formation and theory building and have been valuable in marketing and in the field of consumer science in providing theoretical frameworks for the study of various aspects of consumer behaviour. They have however been criticized in a number of ways in recent years (Erasmus, Boshoff \& Rousseau, 2001: 83-87) and the need to explore alternatives is inevitable.

The fact that scripts contain generic information (thus free from cluttering) and that it is temporal in nature and sequentially ordered, provide the opportunity to elicit and organize a more specific representation of a consumer decision-making event. Because scripts reflect the perspective of the consumer and specify all participants and role players (Schurr, 1986:498-501; Abelson, 1981: 715-718) a more realistic scenario of a specific event such as consumer decision-making could be deduced from a script. Scripts are hereby proposed as an alternative to or, at least, the enhancement of traditional consumer decision-models in an effort to address many of the problems associated with traditional models (Erasmus et al, 2001:83-87).

\section{REFERENCE LIST}

ABELSON, RP. 1981. Psychological status of the script concept. American Psychologist 36(7):715-729.

BOWER, GH, BLACK, JB \& TURNER, TJ. 1979. Scripts in memory for text. Cognitive Psychology 11:177-220.

BOZINOFF, L. 1982. A script theoretic approach to information processing: an energy conservation application. Advances in Consumer Research IX:481-486. Twelfth Annual Conference. [sl]. Association for Consumer Research. BOZINOFF, L \& ROTH, VJ. 1983. Recognition memory for script activities: an energy conservation application. $A d$ vances in Consumer Research X:655-660. Thirteenth Annual Conference. San Francisco. Association for Consumer Research.

BROWN, TJ. 1992. Schemata in consumer research: a connectionist approach. Advances in Consumer Research XIX:787-794. Twenty second Annual Conference. [sl]. Association for Consumer Research.

BURNS, AC \& GENTRY, JW. 1990. Toward improving household consumption behavior research: avoidance of pitfalls in using alternative household data collection procedures. Advances in Consumer Research XVII:518-523. Seventeenth Annual Conference. New Orleans. Association for Consumer Research.

DEN UYL, M \& VAN OOSTENDORP, H. 1980. The use of scripts in text comprehension. Poetics (9):275-294.

DU PLESSIS, PJ \& ROUSSEAU, GG. 1999. Buyer Behaviour. A Multi Cultural Approach. Halfway House. International Thomson. Sigma.

ERASMUS, AC, BOSHOFF, E \& ROUSSEAU, GG. 2001.
Consumer decision-making models within the discipline of consumer science: a critical approach. Journal of Family Ecology and Consumer Sciences 29:82-90.

EYSENCK, WM. 1994. The Blackwell Dictionary of Cognitive Psychology. London. Blackwell.

FORREST-PRESSLEY, DL, MACKINNON, GE \& WALLER, TG. 1985. Metacognition. Cognition and Human Performance. Volume 1: Theoretical Perspectives. London. Academic.

GIBBS, RW \& TENNEY, YJ. 1980. concept of scripts in understanding stories. Journal of Psycholinguistic Research 9(3):275-284.

HOY, MG. 1991. The emergence of script related knowledge. Marketing theory and applications. American Marketing Association Winter's Conference (2):387 - 394.

JOHN, G \& WHITNEY, JC. 1982. An empirical investigation of the serial nature of scripts. Advances in Consumer Research IX:75-79. Twelfth Annual Conference. [sl]. Association for Consumer Research.

LAI, AW. 1994. Consumption schemata: their effects on decision-making. Advances in Consumer Research XXI:489-494. Twenty Third Annual Conference. [sl]. Association for Consumer Research.

LEIGH, TW \& RETHANS, AJ. 1983. Experiences with script elicitation within consumer decision-making contexts. Advances in Consumer Research X:667-672. Thirteenth Annual Conference. San Francisco. Association for Consumer Research.

MARTIN, I. 1991. Expert novice differences in complaint scripts. Advances in Consumer Research XVIII:225-231. Twenty first Annual Conference. [sl]. Association for Consumer Research.

MATLIN, MW. 1998. Cognition. 4 th ed. London. Harcourt. MITCHELL, AA. 1982. Models of memory: implications for measuring knowledge structures. Advances in Consumer Research IX:225-231. Twelfth Annual Conference. [sI]. Association for Consumer Research.

MORRIS, P. 1987. Modeling Cognition. New York. John Wiley.

NOTTENBURG, G \& SHOBEN, EJ. 1980. Scripts as linear orders. Journal of Experimental Social Psychology 16:329347.

PUTO, CP. 1985. Memory for scripts in advertisements. Advances in Consumer Research XII:404-409. Fifteenth Annual Conference. [sl] Association for Consumer Research.

SCHURR, PH. 1986. Four script studies: What we have learnt. Advances in Consumer Research XIII: 498-503. Sixteenth Annual Conference. [sl]. Association for Consumer Research.

SEARLEMAN, A \& HERRMANN, D. 1994. Memory from a Broader Perspective. New York. McGraw-Hill.

SHUTE, VJ. 1996. Learning processes and learning outcomes. In DE CORTE, E \& WEINERT, FE. 1996. International Encyclopedia of Developmental and Instructional Psychology. Munchen. Pergamon.

SMITH, RA \& HOUSTON, MJ. 1986. Measuring script development: an evaluation of alternative approaches. $A d$ vances in Consumer Research XIII:504-508. Sixteenth Annual Conference. [sl]. Association for Consumer Research. SPECK, PS, SCHUMANN, DW \& THOMPSON, CT. 1988. Celebrity endorsements - scripts, schema and roles. $A d$ vances in Consumer Research XV: 69-75. Eighteenth Annual Conference. [sl]. Association for Consumer Research. STOLTMAN, JJ, TAPP, SR \& LAPIDUS, RS. 1989. An examination of shopping scripts. Advances in Consumer Research XVI:384-391. Nineteenth Annual Conference. [sl]. Association for Consumer Research.

STRATTON, P \& HAYES, N. 1993. A Student's Dictionary of Psychology. New York. Edward Arnold.

SUTHERLAND, S. 1995. The Macmillan dictionary of psychology. New York. Macmillan. 
TAYLOR, SA, CRONIN, JJ jr \& HANSEN, RS. 1991. Schema and script theory in channels research. Marketing Theory and Applications. American Marketing Association Winter's Conference (2):15-24.

THAGARD, P. 1998. Mind. Introduction to Cognitive Science. London. MIT Press.

VOSNIADOU, S. Knowledge representation and organization. In DE CORTE, E \& WEINERT, FE. 1996. International Encyclopedia of Developmental and Instructional Psychology. Munchen. Pergamon.

WEISBERG, RW. 1980. Memory, Thought and Behavior New York. Oxford University Press.
WHITE, TW, CURBOW, BA \& COSTANZO, MA \& PETTIGREW, TF. 1983. Social psychological approaches to promoting lifestyle and device oriented conservation behaviors. Advances in Consumer Research X:636-640. Thirteenth Annual Conference. San Francisco. Association for Consumer Research.

WHITNEY, JC \& JOHN, G. 1983. An experimental investigation of intrusion errors in memory for script narratives. Advances in Consumer Research X: 661-666. Thirteenth Annual Conference. San Francisco. Association for Consumer Research. 